\title{
ENGLISH AS A FOREIGN LANGUAGE TEACHERS' BELIEFS ABOUT GRAMMAR TEACHING IN CLASSROOM
}

\author{
Ananda Fitriyani, Silih Warni, Nita Kaniadewi \\ University of Muhammadiyah Prof. Dr. HAMKA \\ anandaftryn@gmail.com, silih1980@gmail.com, nitakaniadewi@uhamka.ac.id
}

\begin{abstract}
This study investigated English as a Foreign Language teachers' beliefs toward grammar teaching in the classroom. This research paper aimed to explore EFL teachers' belief about grammar teaching and the factors influencing teachers in shaping their beliefs on grammar teaching. A qualitative study using a semi-structured interview with eight English as foreign language teachers of secondary schools in East Jakarta has been conducted. The result revealed that most teachers believed that grammar was essential. Explicit grammar teaching was also believed to be more effective to be implemented in teaching grammar, yet teachers still used both explicit and implicit instructions. Nonetheless, some teachers believed that implicit instruction that was suggested in the 2013 Curriculum was less effective due to the limited time of English learning in classroom practice. The factors shaping the teachers' beliefs involved the student factor and the teacher factors which included teachers' prior education and personal experiences. This research was expected to improve the teaching of grammar practices and suggest an effective approach to be implemented in teaching grammar in EFL context for teachers in classroom.
\end{abstract}

Keywords: Teacher's Belief, Grammar Teaching, Explicit and Implicit Grammar Teaching

\section{INTRODUCTION}

Alghanmi \& Shukri (2016) have stated that English language has been considered as a central language used as a bridge for communication among native speakers and non-native speakers around the world, along with the influence of globalization and technology that have been overgrowing nowadays. In terms of education, they also said that in teaching and learning the English language, grammar was believed as an essential element which provides the speaker with the needed patterns in order to arrange words and sentences in a form that is understandable and enable someone to communicate accurately, meaningfully, and appropriately.

In Indonesian education context, English is taught as a foreign language (EFL). It is mainly organized by the Ministry of National Education and Culture, and decreed by law Number 20 Year 2003 about the National Education System and is currently using the 2013 Curriculum (Nur \& Madkur, 2014). In the undergoing Curriculum, communicative language teaching is adopted, where students learn English by observing, questioning, exploring, associating, and communicating (scientific approach).

As a matter of fact, it has been expounded that in 2013 Curriculum, grammar is taught implicitly, expecting that students will comprehend grammar through the learning process. Unfortunately, a study has shown that students in Indonesia had a low level of grammatical quality in their language use (Sugeng, 2015).

The finding above is also supported by the observation that the writer has done in one of lower secondary schools in East Jakarta for 20 days, by teaching English for eighth-grade students and ninth-grade students in one of state secondary schools in East Jakarta, which showed that students had extremely lack of knowledge about grammar. Having knowledge 


\section{ELLTER-J}

Vol.1, No.1. April 2020, 12-24

that the method suggested in 2013 Curriculum does not give much good impacts to grammar learning and teaching, the role of teachers in classroom teaching practice is inevitably important. As stated by Niu and Andrew (2012) in Rahman \& Rashid (2017), it is important to conduct a study towards teacher's beliefs for teacher beliefs are vital components that can give strong effect in teaching practice since it is defined as "teachers' thoughts about what should be done with teaching." Clark and Peterson (1986), in Janfeshan (2018) also pointed out that teachers' beliefs were generally considered a main determinant of instructional activity and of student learning, thus it was important to explore about teachers' belief because it would reflect everything they do in the classroom.

A number of related studies have been conducted on teachers' beliefs about grammar teaching, one of the studies was held by Shukri and Alghanmi (2016) about the relationship between teachers' beliefs of grammar instruction and classroom practices in the Saudi context. The findings revealed that teachers' beliefs were indeed reflected in their classroom practices. Students' proficiency level, attitudes toward the language, needs, learning styles, classroom environment, and teacher development were six factors that influenced the transformation of teachers' beliefs regarding grammar and grammar instruction into practices.

Rahman and Rashid (2017) had conducted a qualitative study on explicit or implicit grammar instructions in higher learning education. The respondents were five educators who taught grammar in ESL classroom. The study found out that educators viewed implicit grammar teaching was important to apply in EFL classroom, yet most of them prefer to use explicit instruction to teach in the class. The study also revealed that the students' needs and institutional requirements play a big role in shaping the teachers' belief.

Önalan (2018) in his study, non-native English teachers' belief on grammar instructions, showed that teacher beliefs were formed according to the learners; explicit grammar teaching was more appropriate to be done to adult learners, meanwhile indirect grammar teaching would suit the teaching of grammar to young learners. They supported explicit grammar exercises and repeated grammar practice as an effective way. However, these teachers also believed that communication-based activity should be emphasized to the students first before teaching explicit grammar.

The focus of the current study is to explore the teacher's beliefs towards grammar teaching practice and the factors that influence the teacher's beliefs in Indonesian education context. Research about teacher's beliefs is important to be conducted since Borg (2006) has exposed that teachers are highly influenced by their beliefs. In addition, as noted by Shavelson and Stern (1981) in Farrell \& Particia (2005), every decision and instruction made by teachers have been filtered according to their beliefs and what teachers do in the classroom tend to be controlled by what they believe. Phipps \& Borg (2009) have concluded that teacher's belief has a powerful effect on teacher's pedagogical decisions which indeed, it is essential to explore teacher beliefs since it may improve their teaching practices and help in suggesting sufficient implications for implementation of teachers' professional development.

Therefore, this research is conducted to investigate EFL teachers' beliefs about teaching grammar in order to enhance the teaching of grammar in classroom practice, and to find out what factors influence EFL teachers in shaping their beliefs towards the teaching of grammar in order to understand what causes the teachers in shaping the held belief for Indonesian education context. This research paper aims answer the following questions; What are EFL teachers' beliefs about grammar teaching? And what factors influence EFL teachers in shaping their beliefs on grammar teaching in EFL classroom? 


\section{METHOD}

In this study, descriptive qualitative data was collected through interview. Rokeach (1968) in Andrews (2003) exposed that beliefs must be inferred from what people said, intended, and did. Pajares (1992) also in Andrews (2003) suggested that belief inventories needed to be supplemented by open-ended interviews in order to gain rich and accurate data. Open-ended interviews encouraged participants to answer the interview in detail impulsively (Popping, 2015). Campbell et al. (2014) as cited in Phipps \& Borg (2009) also said that open interviews could "allow the respondents opportunities to develop their responses in ways which the interviewer might not have foreseen".

The research was conducted in six secondary schools in East Jakarta. They were four lower secondary schools and two upper secondary schools. The collection of the data for the research was held from April 25 $5^{\text {th }}, 2019$ until May $24^{\text {th }}, 2019$. The participants of this study were selected through purposive sampling. The participants must have experienced in teaching English for students from $7^{\text {th }}$ until $12^{\text {th }}$ grades in secondary school. Thus, eight EFL teachers of six lower and upper secondary schools in East Jakarta were the participants of this research. Three participants were teaching in lower secondary schools, one participant was teaching in upper secondary school, two participants were teaching in the same upper secondary school, and two other participants were teaching in the same lower secondary school, as seen in the table below;

Table 1: Participants of the Study

\begin{tabular}{|l|c|l|c|}
\hline Teachers & $\begin{array}{c}\text { Years of Teaching } \\
\text { Experience }\end{array}$ & \multicolumn{1}{|c|}{ Place of Teaching } & Education Background \\
\hline Teacher 1 & 34 years & Lower secondary school & Bachelor \\
\hline Teacher 2 & 21 years & Lower secondary school & Master \\
\hline Teacher 3 & 16 years & Lower secondary school & Bachelor \\
\hline Teacher 4 & 5 years & Lower secondary school & Bachelor \\
\hline Teacher 5 & 3 year & Lower secondary school & Bachelor \\
\hline Teacher 6 & 32 years & Higher secondary school & Bachelor \\
\hline Teacher 7 & 8 years & Higher secondary school & Bachelor \\
\hline Teacher 8 & 5 years & Higher secondary school & Bachelor \\
\hline
\end{tabular}

An interview was the instrument to obtain qualitative data that could reveal teachers' beliefs on grammar teaching, and the factors affecting their beliefs. The interview was the adapted version used in Rahman and Rashid's qualitative study (2017), containing of openended items that invite teachers to describe or comment on an issue specifically. There were six items for the interview. Three items were used to answer the first research question, which was about the teachers' beliefs about grammar teaching. Meanwhile, three other items were used to answer the second research question, which was dealing with the factors that shaped their beliefs. The interview asked the teachers about their beliefs about grammar in language teaching, and the instructions used in teaching grammar (explicit and implicit). Next, the interview asked the teachers about the factors that shaped their beliefs, which also questioned about the teacher's experience of learning grammar in school and university, the role of students being taught, and the school where the teacher was working. The interview was conducted using Bahasa Indonesia. All the interviews were audiotaped, and later transcribed. 


\section{ELLTER-J}

Vol.1, No.1. April 2020, 12-24

After collecting the data, the writer transcribed all the interviews that have been conducted into interview transcripts. After that, the writer read all the interview transcripts thoroughly, and interpreted the data. The data would later be divided into themes by coding the data. The coding of the data was aimed to connect the similar and dissimilar portions in the data (Ibrahim, 2012).

First, the researcher did the coding of the data in each of participant's interview transcript to find the patterns and the relevance of any statements, including both the similar responses and different responses. Later, the researcher connected all the patterns found from each participant's interview and grouping it according to the similarities of the variables into themes that interpreted the whole data.

\section{FINDINGS AND DISCUSSION}

The result indicated four themes, which are positive beliefs, less positive beliefs, teacher factors, and student factors. Teachers had positive belief towards grammar teaching in which it was considered important and the instructions used in teaching grammar, which were explicit and implicit. Nevertheless, there were fewer positive beliefs about the instruction, which is implicit, that was suggested in the 2013 Curriculum. It also showed that student factors and teacher factors, which included teachers' school experiences and teachers' personal experiences, were the factors in shaping the teacher's belief towards grammar teaching.

The findings showed that teachers' positive beliefs of grammar teaching involved the importance of grammar in English language teaching and the instructions used to teach grammar, which were explicit and implicit, followed by the responses of the students.

Mentioning the importance of grammar teaching, all the participants expounded that they had a strong belief that grammar was essential in English language teaching as a foreign language. This can be seen as one teacher said that grammar was important to guide both students and teachers in conducting proper communication to deliver and understand the meaning properly, as she explained,

Grammar was the most important thing in English language teaching since it could guide us; not only for the students, but also us teachers to speak properly. Communication meant that we had to understand the meaning. But in order to understand the meaning, we had to use the rules properly.

In addition to its function in communication, Teacher 4 revealed that grammar was undoubtedly necessary for academic purpose. The knowledge of grammar could be the most essential point for students in constructing a proper sentence or even a paragraph, as well as understanding its meaning. The capability of forming correct sentences and paragraphs was undeniably needed since students had to make essay writing and any other writings properly throughout their education journeys.

In addition to the importance of grammar, the participants also had positive belief towards the grammar teaching instructions in the EFL classroom, which were explicit and implicit. Speaking of teaching grammar explicitly, it was seen that all the participants believe that clear presentation in teaching grammar was effective. It was shown that presenting grammar explicitly had a significant chance to make students understand about grammar. Teacher 2 mentioned that it was important to build students' understanding about basic grammar material such as the part of speech. 


\section{ELLTER-J}

Vol.1, No.1. April 2020, 12-24

Teaching the students about tenses explicitly was also believed to be more efficient since it had many patterns that the students needed to know, in order to form a proper sentence or paragraph according to the time references (present, past, and future). Teacher 4 and Teacher 5 explained that students were required to have a good knowledge of the basic grammar material first if they wanted to be able to understand another grammar material such as if clause and passive voice. Supporting Teacher 4 and 5's statements, teacher 7 disclosed that he had always been using explicit instruction in teaching grammar materials that require some patterns to be implemented, as can be seen in the following extracts of the interview.

When students were going to make a sentence or a paragraph, at least they were supposed to understand the part of speech such as the verb, adjective, etc. It would be best to present this material explicitly to give them clear understanding.

It was exposed that some participants had the notion that teaching grammar explicitly would be best for some grammar materials. This positive belief about teaching grammar explicitly was also supported by positive responses of the students when being taught explicitly. Teacher 7 discovered that when teaching grammar explicitly, his students were very enthusiastic since they were curious about the material, even for basic grammar material, which in fact, had not been understood yet by them. Indeed, giving the students an overt grammar explanation helped them a lot in understanding the material that they gained an increasing score at the final test. Apparently, Teacher 2 had the same thought as Teacher 7, as she disclosed,

When being taught explicitly, they (students) understood better, I would say. It can be seen that, they passed the test that I gave with good score.

It was seen that both teachers and students held positive beliefs and responses towards teaching grammar with explicit presentation. Teachers believed that teaching grammar explicitly was suitable to introduce some grammar materials to enhance students' understanding. This belief was also approved by the positive responses of the students when being taught explicitly that it helped them improving their test score.

Besides the positive belief of explicit presentation in teaching grammar, three out of eight teachers still believed that implicit presentation also gave positive impact. Teacher 4 and Teacher 5 preferred implicit instruction to teach some grammar material by bringing the students into a situation, where the grammar material was required to be used for expressing statement in such situation. Teacher 8 also agreed that teaching grammar implicitly was effective to construct the student's comprehension by taking them into the related situation when the grammar material was used, as he stated,

Since my students were teenagers, I thought presenting grammar material implicitly worked best. It was easier to take them into particular situation, or by giving them illustration. So, I'd start building their comprehension by the situation and illustration given.

Nevertheless, even though three out of eight participants gave positive comments on implicit grammar teaching presentation, the rest of participants held less positive belief towards implicit grammar teaching which was more influenced by the students' responses. Teacher 1 revealed that implicit way of teaching grammar was not very effective, since the 


\section{ELLTER-J}

Vol.1, No.1. April 2020, 12-24

students had extremely lack of English exposure and knowledge, that they would not be aware of the grammar if the teacher did not give a clear explanation.

The notion was followed by Teacher 2 and Teacher 3 who held the same belief of implicit grammar teaching. These teachers stated that whenever grammar was taught implicitly, it was hard to make the students understood about the material. In the end, an overt explanation was still needed, otherwise students were still confused. In addition, Teacher 8 explained that implicit grammar teaching was challenging to be implemented since he had to think about achieving targets required by the school, as he clarified,

I believe that teaching grammar implicitly is just not very effective, especially we have goals to be accomplished. It takes a long time to make students understand when I teach them grammar implicitly.

The commentaries of the participants above showed that teaching grammar implicitly was considered not very effective to be applied since they depended on the students' less positive responses when being taught grammar implicitly. Furthermore, Teacher 8 has stated that teaching grammar implicitly would take a longer time to make students understood, meanwhile it was hazardous since they had to reach targets for the mid and final semester test.

Another thing that participants believed as less positive was the external requirements which are English language teaching, especially grammar in the 2013 Curriculum and suggestion from MGMP. Speaking of the 2013 Curriculum, some teachers complained about the portion of grammar suggested in the 2013 Curriculum. Teacher 2 explained how she held less positive belief about grammar teaching in the 2013 Curriculum,

I have always been teaching grammar explicitly. Unfortunately, in the 2013 curriculum grammar should be taught just implicitly. For me, teaching grammar implicitly is not that effective, but, it's a command in the 2013 curriculum so I have to teach them implicitly sometimes. Also, in 2013 curriculum Bahasa Indonesia subject is given 6 hours meanwhile English language is only 4 hours a week. It's just that we have a lack of portion in teaching and learning English in class, implicit learning takes longer time, we need more time.

Teacher 2 thought that the demand for grammar teaching and learning in 2013 Curriculum was not just in line with what was occurring in class. She thought that grammar teaching by implicit presentation needed a longer time to be implemented effectively, meanwhile the time allocation of English language given in school was not enough. In line with Teacher 2, Teacher 5 expressed her disappointment as well about the minimum portion of grammar in 2013 Curriculum, as she stated,

My students are interested whenever I teach them about grammar, they have the most curiosity in grammar compared to other material. Unfortunately, grammar is not that often being taught since it is rarely comes up in English language subject.

Regarding the irrelevant relation between the demand of teaching grammar implicitly as suggested in 2013 Curriculum and a little time allocation of English language teaching in school, Teacher 1 also complained and ignored the requirement to teach students implicitly, yet teaching them explicitly instead, as exposed, "What I belief is that, we still have to teach 
grammar. Even though they (2013 Curriculum) said that we may not teach grammar explicitly anymore, I still give clear explanation of grammar to my students to make sure that they understand the material well.

Thus, it was shown that teachers held less positive belief towards teaching grammar implicitly that was suggested in 2013 Curriculum. Moreover, considering the little amount of time of English language teaching in classroom arranged by 2013 Curriculum, teachers believed that teaching grammar implicitly as suggested in 2013 Curriculum and MGMP was not very effective.

All the participants claimed that they perceived the belief about grammar teaching mainly from experiences which involved their school experiences and personal experiences. Teacher 1 and Teacher 3 expressed that their beliefs about grammar were highly influenced and constructed by their prior school experiences, as learners. Grammar had been taught strictly to them and it made them realize that grammar was important.

In addition to school experience, Teacher 3 and Teacher 5 revealed that they formed their beliefs as it was influenced by their personal experiences. A belief was shaped as they observed somebody talking improperly; using time signals in the context of speaking that they could not understand well.

Furthermore, there was other influences that came from students in forming teachers' belief about grammar, particularly on how grammar teaching should be presented in classroom as teacher 2 confirmed,

Since English is a foreign language in Indonesia, students are going to make denial as, 'English is not for us'. We need to motivate them and tell them that English language and grammar is important for their own future. Furthermore, they really have less exposure of English language and I still have to make them understand since the very beginning for most of students don't even know what is verb, adjective, noun, and all the basic knowledge about grammar.

It is said that students had a little knowledge for studying English and that they still needed to be taught grammar in details to make them aware of every component in grammar material.

\section{DISCUSSION}

As stated in the findings above, it is revealed that there are positive beliefs and less positive beliefs. Positive beliefs talk about the importance of grammar and the instructions that are used in teaching grammar (explicit and implicit instructions), meanwhile fewer positive beliefs implicit instruction in grammar teaching as suggested in 2013 curriculum.

It is declared that all participants hold the same positive belief focusing on the importance of grammar. Grammar is valued as important since it is a guidance in a language on how the words and sentences are being put together properly in order to perceive and deliver meaning in communication (Nunan, 1999 in Kong, 2008). Thus, it is claimed that grammar also plays important role in guiding someone to have an efficient communication and to reduce misunderstanding (Alghanmi \& Shukri, 2016).

Regarding the instructions used to teach grammar, all the respondents also have positive belief towards both explicit and implicit instructions. Nevertheless, most of the respondents prefer explicit grammar instruction since it is sufficient to make students understand grammar better. Moreover, Loewen \& Sato (2017) has concluded that in Spada \& Tomita (2010), using explicit instruction to teach grammar is considered more effective. This 
is in line with the research that is conducted by Rahman \& Rashid (2017) which find out that teachers choose to teach grammar explicitly since it assists students to have high accuracy when they are using the language for communication.

In addition, the respondents in this study also describe positive responses from their students when grammar is being taught explicitly, such as their students' enthusiasm and the increasing test result of their students. To support the statement above, Janfeshan (2018) has asserted that teachers use approaches to grammar instructions according to their students' expectations, meanwhile in Schulz $(1996,2001)$ as cited in Janfeshan (2018), it is shown that language learners fiercely look forward to explicit grammar instruction.

Although most respondents prefer explicit instructions to teach grammar, three respondents believe that implicit instruction where grammar is taught by giving exposure of the language by focusing on the meaning in communicative approach (Larsen-freeman, 2015), is also proper to be implemented. One respondent even reveals that his students respond positively since implicit learning in class can give stimulus to students to enjoy the learning session by giving them example of situation and illustration. In fact, students' feelings of enjoyment when learning is actually suggested since it is in line with Asher's learning hypotheses that says "the lower the stress, the greater the learning." (Richards \& Rodgers, 2001). Krashen (1981) as cited in Murniati \& Riyandari (2017) has exposed that the most efficient way to teach grammar is by using implicit instruction where students learn grammar that is used in real situation in a fun and interactive way.

However, even though three respondents support implicit instruction, the rest of the respondents in this study hold less positive belief towards implicit direction. These respondents consider implicit grammar teaching as ineffective to be implemented to their students due to the lack of time allocation given for English language teaching in school every week. Deng \& Lin (2016) also find out that due to the limited time and limited competency of the students to absorb grammar rules by themselves when being taught implicitly, teachers believe that it is more efficient to teach grammar explicitly.

The findings in this study also report that considering the condition of the students that do not have enough English exposure, implicit presentation of grammar teaching is quite risky since teachers also have to consider the score target from middle and final test that should be achieved. As a result, teachers keep teaching grammar through explicit instruction; otherwise, they will not reach the goal required by the school. That is also in line with research from Rahman \& Rashid (2017) that shows teachers prefer explicit instruction since implicit instruction will take a longer time for students to understand and is contrary with the condition of English language teaching that is only conducted in a little portion of learning time every week.

It is clear that respondents believe that explicit grammar instruction is considered more effective than implicit grammar instruction to be conducted. However, they still manage to use implicit instruction in teaching grammar since there is demand from external requirements, which are 2013 Curriculum and MGMP which is believed as less positive as well by the respondents. Besides, some respondents also divulge that they are not pleased with the limited time allocation per week to teach English arranged in 2013 Curriculum.

In 2013 Curriculum, scientific approach, where students are expected to experience discovery learning through five stages: observing, questioning, exploring or experimenting, associating, and communicating is implemented (Widodo, 2016). Unfortunately, the scientific method in current curriculum does not give a good impact on students' knowledge of grammar (Wahyudin \& Sukyadi, 2015). 
Since the 2013 Curriculum is applied, it is shown that students' ability in speaking fluently is achieved, yet the fluency is not followed by grammatical accuracy. In fact, it is found that students' English language use has extremely poor grammar knowledge. Consequently, the teaching of grammar is urgently needed to be maximized (Sugeng, 2015). Apparently, a habit formation in learning a language should be taken into account in order to build and increase language proficiency. Thus, when time allotment is limited and not enough, the habit formation to develop students' proficiency in language use will be improbable to be occurred (Panggabean, 2015). Even though these teachers believe that teaching grammar implicitly to students is ineffective, they still consider implicit instruction as mandated in the 2013 Curriculum to be implemented in the class. Even though teachers give implicit instruction to teach grammar, they assert that most of the time explicit instruction is still used.

Speaking of the factors that shaped the teachers' beliefs on grammar teaching, there are two main factors that influence teachers in shaping their beliefs toward grammar and grammar teaching which are teacher's factors and student's factor. The belief about grammar and grammar teaching is sourced by teachers' factors involving teachers' prior education experiences and teachers' personal experiences. Meanwhile, their beliefs about grammar teaching on how grammar should be taught in class is mainly influenced by the student factor which is talking about students' lack of knowledge about grammar.

The participants enclose that their prior education, especially in school, plays a big role in forming their belief about grammar. This finding is in line with study by Rahman \& Rashid (2017) which shows that education institution such as school and university is likely to lead teachers in constructing their belief. Nurusus et al. (2015) have stated in their study that Ezzi (2012), also Abdullah and Majid (2013), teachers' school experiences can be a potential factor in constructing their beliefs.

In addition to their school experiences, the teachers also confess that their personal experiences and thoughts have led them to shape their beliefs about grammar. Their personal experiences include the function of grammar in communication which is to deliver and transfer the meaning well. These teachers have experienced communicating without grammar and it is resulting in negative impact. Indeed, "communication can generally be achieved most efficiently by means of grammatical sentence or by a series of such sentences logically related" (Close, 1991; p. 14, as cited in Zain, 2007).

The participants view that their students are the factor in shaping their beliefs toward how grammar should be taught in classroom practice. The participants view that their students have very low proficiency in English language, especially in grammar. In line with this, Sugeng (2015) also finds out that students always make mistakes in every sentence they asked to make and are unaware about the mistakes they are making, which shows that the students' understanding about grammar is impoverished.

The finding is followed by a study from Rahman \& Asfah (2018) that discloses English subject in Indonesia is formally given to students at the first year of lower secondary school, with a very weak competency in English materials. The statement is proved by the inability of students in making even simple sentences that they immensely missed out the accuracy. Rahman \& Afsah have argued that the impoverished level of students' English mastery is caused by the insufficient time of exposure to English language and the deficiency of explicit instructions of grammar. Furthermore, in the current study, the participants believe that in order to fix the situation and make the students comprehend grammar completely, explicit instruction with a clear explanation needs to be occurred. It also should be considered to give attention to the time constraint of English language teaching in school. 
However, there is a contrary argument from Savage (2010) that it is asserted that teaching grammar implicitly to students with low competency of grammar and little exposure to English might be more effective. This statement is contrary to the teacher's belief about grammar teaching. Indeed, implicit grammar teaching will effectively occur if students make use English language to communicate as a habit, for proficiency of language is only going to be perceived well when the language is used actively (Paggabean, 2015).

However, the limited time to learn and use English, in fact, worsen the students' awareness in learning accuracy in English that it might only result in low achievement (Panggabean, 2015). Due to these reasons, which are the lack of knowledge and time in learning English especially grammar, the participants believe that they must teach their students from the very beginning by giving an overt explanation about grammar.

\section{CONCLUSION}

In summary, this research has qualitatively explored the teachers' beliefs about grammar and the factors influencing the held beliefs. Mentioning the teachers' beliefs about grammar, there are positive beliefs and less positive beliefs. Speaking of positive beliefs, the findings clearly show that grammar is considered important. Explicit grammar teaching is also believed to be more effective to be implemented in teaching grammar. Nonetheless, teachers still use both explicit and implicit instructions when teaching grammar, depending to what grammar material is going to be learned.

Even though some teachers consider that both explicit and implicit grammar as positive beliefs, they also believe that teaching grammar implicitly might be less effective due to the less positive responses of their students when being taught that way. Implicit instruction to teach grammar is considered as less positive belief yet it is still used by the teachers due to the mandate given in 2013 Curriculum. It is evident that these teachers hold less positive beliefs towards English teaching and learning, especially for grammar in the 2013 Curriculum. Beside the implicit teaching mandated in 2013 Curriculum, teachers also complain about the time constraint of English teaching in classroom per week. The little portion of English language teaching and learning in class is just irrelevant with the suggestion of teaching grammar implicitly since students need to get used to the language to reach the language proficiency.

The findings also answer to the question of the factors of the teachers' beliefs which involve the teacher factors and the student's factor. It is illustrated that the teachers' prior experiences of education profoundly influence them in shaping their belief about grammar. It is shown as they report to the writer about how their teachers always emphasize them to learn grammar that it is very important. In addition to their school experiences, their personal experiences of having realized the importance of grammar in communication also give contribution in forming their beliefs toward grammar. Indeed, grammar is inevitably important to build meaningful communication.

About grammar teaching, the students are the factor that constructs the teacher's beliefs toward instructions to be presented when teaching grammar in the classroom. It is shown that the students' poor knowledge of grammar and little time spent of using English are the factors that encourage teachers to believe that they must teach grammar explicitly with an intelligible explanation.

Based on the result of the interview, the writers provide some suggestions to each of teachers and policymakers of curriculum. For teachers, explicit and implicit instructions are not supposed to be judged that one is better than the other one, but it complements each other for different materials and situations instead. Thus, teachers should be able to wisely use the 


\section{ELLTER-J}

Vol.1, No.1. April 2020, 12-24

two instructions equally. For example, teachers can provide a supplementary learning media to help students cope with the difficulties when being taught grammar. Teachers can also try to search another references related to the various way of teaching grammar.

For the policy makers of the curriculum, there is nothing wrong with implicit instruction being mandated for the teachers in teaching grammar. However, the extremely limited time of teaching and learning English in class for students might be not a very good decision since many students are having a lack of exposure and are only using English properly in the classroom. It would be better to consider extending the time of English teaching and learning in school per week. It is also better to conduct events that are related to English language to make EFL students get used to English language such as English day, where in that day everyone is required to speak in English. That way, students can perceive enough exposure to English language.

\section{REFERENCES}

Abdullah, N., \& Ezzi, A. (2012). Yemeni teachers ' beliefs of grammar teaching and classroom practices. English Language Teaching, 5(8).

Alghanmi, B., \& Shukri, N. (2016). The relationship between teachers ' beliefs of grammar instruction and classroom practices in the Saudi context. English Language Teaching, 9(7).

Andrews, S. (2003). "Just like instant noodles": L2 teachers and their beliefs about grammar pedagogy. Teachers and Teaching: Theory and Practice, 9(4), 351-375.

Borg, S. (2001). Self-perception and practice in teaching grammar. English Language Teaching, 21-29.

Boucher-Yip, E. (2017). English language education policy in Asia. Current Issues in Language Planning, 18(2), 236-240.

Ellis, R. (2006). Current issues in the teaching of grammar. TESOL Quarterly, 40(1), 83-107.

Farrell, T. S. C., \& Particia, L. P. C. (2005). Conceptions of grammar teaching: a case study of teachers ' beliefs and classroom practices. Tsel-Ej, 9(2), 1-13.

Graus, J., \& Coppen, P. A. (2016). Student teacher beliefs on grammar instruction. Language Teaching Research, 20(5), 571-599.

Ibrahim, M. (2012). Thematic analysis :a critical review of it process and evaluation. West East Journal of Social Sciences, 1(1), 39-47.

Janfeshan, K.-. (2018). Iranian EFL teachers' beliefs about how to teach English grammar. BELT - Brazilian English Language Teaching Journal, 8(2), 335.

Kong, J., \& Teaching, G. (2008). About grammar and gammar teaching Final Year Project submitted in Partial Fulfillment of the Requirements for the Degree of Bachelor of Education with Honours ( TESL ) Faculty of Cognitive Science and Human Resource Development Gred : (12077). 


\section{ELLTER-J}

Vol.1, No.1. April 2020, 12-24

Larsen-freeman, D. (2015). Research into practice: Grammar learning and teaching Research. Language Teaching, 48(2), 263-280.

Loewen, S., \& Sato, M. (2017). Grammar acquisition. In Nassaji, The Routledge Handbook of Instructed Second Language Acquisition (pp. 205-218). Third Avenue, NY: Routledge.

Madkur, A. (2014). Teachers' voices on the 2013 curriculum for English instructional activities. Ijee, 1(2), 120-134.

Murniati, C. T., \& Riyandari, A. (2017). The implication of pre-service teachers belief about grammar teaching and learning for English language policy in Indonesia. Celt: A Journal of Culture, English Language Teaching \& Literature, 16(1), 133.

Önalan, O. (2018). Non-native English teachers ' beliefs on grammar instruction. English Language Teaching, 11(5), 1-13.

Phipps, S., \& Borg, S. (2009). Exploring tensions between teachers ' grammar teaching beliefs and practices. System, 37(3), 380-390.

Rahman, A. M. A., \& Rashid, R. A. (2017). Explicit and implicit grammar instructions in higher learning institutions. English Language Teaching, 10(10), 92.

Rahman, M. A., \& Asfah, I. (2018). Some effects of explicit grammar instruction and syntactic priming on students' written language production. SHS Web of Conferences, $42,1-8$.

Rajab, H. (2013). Theory and practice in language studies. Theory and Practice in Language Studies, 3(4), 653-659.

Savage, K. L. (2010). Grammar Matters. New York, USA: Cambridge University Press.

Sugeng, B. (2015). Need for increasing grammar focus in English teaching: a case in Indonesia. Journal of Educational and Social Research, 5(3), 131-138.

Wahyudin, A. Y., \& Sukyadi, D. (2015). A closer look at the implementation of the curriculum 2013 in Indonesia: should the scientific approach be used in EFL classroom?. Rangsit Journal of Educational Studies, 2(2), 56-70.

Zheng, L. (2015). Explicit grammar and implicit grammar teaching for English major students in university. Sino-US English Teaching, 12(8), 556-560. 


\section{APPENDIX 1}

\section{Interview Questions}

a. Background Information

1. What is your educational background?

2. How many years have you been teaching?

3. Which grades are you teaching?

b. Questions about teacher's beliefs

1. What do you believe about grammar in language teaching?

2. How do you view explicit and implicit instructions of grammar teaching?

3. In your belief, how is the most suitable way in teaching grammar for EFL students?

c. Questions about factors that shaped teacher's beliefs

1. How does this belief about grammar formed?

2. How is the school/institution's role that leads you to choose the instruction in grammar teaching?

3. How is the students' role that leads you to choose the instruction in grammar teaching? 